\title{
Smartphones in Child Upbringing During Early Childhood: Hazards and Possibilities from Mothers' Perspective
}

\begin{abstract}
The article presents the results of research that pertained to the manner of smartphone use in child upbringing during early childhood. The qualitative research was participated in by: a mother of a two-year-old girl and a mother of a threeyear-old boy. On the basis of the tests I concluded that this device is mainly used by mothers: - to occupy the attention of the child, to allow the mother to perform other activities, - to calm the child down at times of anxiety, - as a reward. The interviews have shown that for the respondents the educational function of smartphone are not significant, although they see them.
\end{abstract}

Keywords:

early childhood, smartphone, education, family upbringing

\section{INTRODUCTION}

The turn of the 20th and the 21st century brought about many social, cultural and technological changes. They are of great importance in various areas of human activity, creating brand new conditions for the development of not only teenagers and adults, but also, increasingly, younger children. Life experiences of the modern child are, in many respects, completely different from the experiences of children growing up in the 1980s or 1990s. Modern children - "digital natives"

Faculty of Early School Pedagogy and Media Pedagogy, Department of Pedagogy and Psychology, University of Silesia, Katowice, Poland, E-MaIL: tomasz.huk@us.edu.pl. 
- cannot imagine a world without computers, the Internet or mobile phones as a result of the exposure to digital communications of the Internet (Berk, 2009).

The use of new media in upbringing pre-school children is a crucial aspect undertaken in scientific studies due to the commencing period of preparing the children for school (Huk, 2013). The importance of this study is underlined by many researches who suggest continuing research to monitor longer term implications (Bassiouni \& Hackley, 2013). Research into early childhood in a reality dominated by "new media" is not often raised in scientific deliberations, therefore it is so important to expand knowledge in this field.

\section{THEORETICAL BASIS FOR THE CONDUCTED RESEARCH}

Assuming, after Bogusław Śliwerski (2012, pp. 28-29), that upbringing of the child is "[...] an effect of actions or processes, the indicator of which is to effect changes in personality or behaviours [...]” (own translation), we can intentionally plan their development. Since modern children live in the age where upbringing activities and processes are often related to new media such as the Internet and mobile devices, they have been aptly described by Marc Prensky (2001) as "digital natives." These are children who, without trepidation and very intuitively, successfully work out the functionalities of media appearing in their lives. In early childhood, these changes are mostly the result of upbringing activities of parents versed in the use of digital media. Initially, they perform the role of people satisfying all the needs of the child and subsequently help them in satisfying those needs on their own through said media. This process, in accordance with the thesis of Applet and Mielcarek (2014), consists of gradually reducing control and allowing children an autonomous use of the television, tablet, computer and smartphone. These media "due to their properties, i.e., interactivity, gathering and disseminating knowledge, are an important factor of social evolution”(Siemieniecki, 2013, p. 157, own translation).

An important aspect of the conducted research was to identify the frames of the childhood development period in the context of used digital media. This problem was noted by Jacek Pyżalski (2017), who recalled the opinion of developmental psychologists. They emphasize that the manner of using digital media is diverse in individual age groups, and propose the adoption of two-year intervals 0-2 and 3-4 years of age. On the other hand, Kinga Kuszak (2017, p. 10, own translation) indicates that "childhood" "is a time in life beginning with birth, and ending with changes indicating the beginning of adolescence. This development 
stage is divided into three phases: early childhood, pre-school age and junior school age.” In the described research perspective, I was interested in the section concerning the final stage of early childhood, characterised by the shaping of a sense of autonomy. The child more and more often wishes to be independent from the mother, to discover and learn about their surroundings on their own. The child is able to move around more and more proficiently. In this period, children begin to move around on their own, walk, run, jump, climb the stairs, start riding tricycles and manipulate objects with increasing proficiency. Through observing adults, they try to use objects in the same manner, learning about their intended use. The described age is characterised by a greater sense of awareness. Children develop a tendency to possess, an awareness of their own "Self", they start developing their vocabulary. The child starts to construct sentences in accordance with grammatical rules, and learning is a spontaneous process effected through imitation. During this period, contact with other children and adults increases (Applet, 2005).

In early childhood, a toy, or rather a teaching aid assisting in the upbringing process, increasingly more often employed by parents, is the smartphone. This device is defined as: an intelligent phone, a mobile phone with a touchscreen. A smartphone is equipped with programmes to manage personal information and an operating system that permits installation of other computer software for browsing the Internet, e-mail, music, videos and other applications. A smartphone may be treated as: a portable computer, a photographic and video camera integrated with a mobile phone (see: Hosch). Since one of the factors determining the educational future of the child are the upbringing skills of the parents (Björklund \& Salvanes, 2010), their competence in using a smartphone may be connected with specified changes in the children's personalities.

The research conducted in South Korea among 322 mothers of young children who go to early childhood education institutions has shown that children use smartphones at around the age of twenty five months and frequently they use it for about sixteen minutes once a week (Kim \& Kang, 2016).

This thesis is confirmed by, i.a., tests conducted by scientists from Northwestern University and VJR Consulting, on a sample of 2300 parents of children aged $0-8$. Their results indicate that the time spent on using smartphones by children is strongly dependent on the attitudes of parents towards this medium. That means that frequent use of smartphones by parents increases the frequency of it being used by children (Lauricella, Wartella, \& Rideout, 2015). Scientists confirmed that for most parents with children of eight years or less "old and new media" are actively used in parental practices. These media occupy the children's atten- 
tion, calm them down, discipline and reward them (Wartella, Rideout, Lauricella, \& Connell, 2014). Other tests, conducted on 85 Turkish parents, indicated that preschool children do not use a smartphone for educational purposes but primarily to play games, which is the reason for concern of the parents (Genc, 2014). Anxiety connected with the use of modern technologies is also confirmed by British research based on a sample of 346 families, although it should be added that respondents do not perceive new media as a threat to contemporary childhood (Plowman, McPake, \& Stephen, 2011).

Taking into account that in Poland smartphone has become more and more popular, it is important to discover how Polish parents use smartphones during upbringing process.

Therefore, my research was focused on small children, especially under the age of three and their mothers, which play significant role in the first years of children's life. Moreover, "the detailed mobile parenting is likely to be carried out by mother, while the father has more fundamental control of all family members" (Yoon, 2003). Mothers "have been also found to be a reliable source for news on baby development and more interested in main time family media records" (Madge \& O’Connor, 2006).

The object of my focus in describing the phenomena included: - parent satisfaction when they see a child sitting peacefully in front of the computer screen, tablet, smartphone or TV (Kuszak, 2017); - checking whether parents who use the Internet more often and have greater knowledge in the scope of the inner workings thereof, are more aware of the accompanying hazards. On the other hand, the lack of knowledge is translated into less control of the parents (Batorski, 2017); - the negative myth concerning digital media related to the belief that childhood should be free of technology and the optimistic myth, propagated by some parents, that allowing children to use technology from an early age is an investment in their future - an adult life in the digital world (Plichta, 2017); - hazards arising from the child using digital media, which constitute a hazard for the physical, cognitive, emotional and social development, dominance of information-communication technology in the child's activity, hazards connected with the use of the Internet (Pyżalski, 2017).

\section{OWN RESEARCH METHODOLOGY}

The research area I explored was the upbringing reality in the families of a 2- and 3 -year-old child. In result of analysing the literature, I formulated the following 
problems: Why and how do mothers use smartphones in upbringing a 2-year-old and 3-year-old child? What are the possibilities and hazards in using the smartphone in upbringing in the opinion of the mothers taking part in the research?

The conducted research was qualitative (Juszczyk, 2013), and thus, despite the fact that it may not be generalised to the entire population, it indicates a certain direction for conducting consecutive verification tests. In order to answer the posed research problem, in July 2017 I carried out an individual in-depth interview with little guidance (Rubacha, 2008) with the mother of a two-year-old girl and a mother of a three-year-old boy. The interview was conducted in accordance with the theoretical assumptions presented above. Due to the specific criteria included in the research problem, the interview included women selected in a purposeful manner. The criteria concerned, inter alia: to be the first time mother, having baby under three-year-old, be employed and having high level of education and media skills. It was also important that the sex of children was different, because it could cause different approach towards using new media in upbringing. Therefore, in conducted research, one mother of baby boy and one mother of baby girl took part.

The first respondent, at the time of the test, was thirty years of age, completed her master's degree in "social communication" at the political science department. She also completed tertiary education in public relations, a one-year course in advertising photography, and graduated from coaching school. She also completed several courses related to media. She is married and has a two-year-old child - a daughter. She is professionally involved with social media, has an active account in all Polish social media, and is active in NGOs, which include the Polish Scouting and Guiding Association (ZHP). Therefore, the respondent had a very high level of competence in the scope of media usage. The second respondent, at the time of the test, was forty one years of age, completed her master's degree in political science and postgraduate studies in economic and trade law. Professionally, she is involved with an international corporation operating in the field of rail transport. The respondent has a high level of competence in media usage and has an active Facebook account. She is married and has a three-year-old child - a boy.

\section{RESULTS}

First, it should be mentioned that the mother describing her experiences in upbringing a two-year-old daughter is very conscious in the use of social media. The respondent does not treat smartphone as an educational medium and does not 
install educational application thereon. She admits however that her daughter has learned several words from a cartoon she watched on smartphone. The mother prefers "offline" entertainment for her child, such as crayons and a sheet of paper because she is aware that what is digital and online is simpler and "the world of moving pictures is more appealing." Despite such preferences, the parents do not read bedtime stories to the child because, as pointed out by the respondent, she does not have trouble going to sleep. She adds: "somehow, the trend of bedtime stories hasn't affected me yet. I think that the moment will come eventually.” A different account is given by the mother of the three-year-old boy, who reads him a bedtime story every night before he goes to sleep. For him, this is a ritual, therefore he insists to be read to.

It happens that contemporary parents use the smartphone to calm the child down or occupy the attention thereof. This function of the smartphone device known as the "digital pacifier" is also used by the respondent in the upbringing process. The mother admits that in a situation when she needs to perform an activity (ca. 6 minutes) she gives her daughter a cartoon or pictures to watch on a mobile phone. She emphasises that there are also situations when her daughter is very frustrated, she does not want to do something, it is hard to calm her down and that is when smartphone, in the role of a "calming down agent" [digital pacifier T.H], is of use. On the other hand, the second respondent never gives a smartphone to her child to get him to calm down or as an attempt to alleviate anxiety, in fear that he will develop bad habits. Then again, the boy is allowed to use the smartphone when the respondent needs to speak with someone, when she is at the hairdresser's, or as a reward for a good behaviour.

The interviewee is aware of the fact that her daughter is learning through observation, therefore she takes care that no one uses their phone during meals, so that the daughter feels that she has everybody's undivided attention. She emphasises that a situation when "we play with our daughter and look at Facebook with the other hand" should never happen. Later, however, she admits that "we're not perfect because we sometimes do just that. Although I try to keep myself in check, so the phone doesn't tempt me." Similar sentiments are held by the mother of the boy, who regretfully states that although she herself does not use her phone during meals, her husband is unable to let go of it. She admits that sometimes the child eats while watching cartoon on a smartphone.

The described two-year-old girl likes to use digital media, which does not mean it is a permanent condition. The mother describes the desire to play with these media comes about in result of the child observing that someone is using a phone or sees the remote control for the television set. The two-year-old knows 
how she wants to use the phone, however the final decision is made by the mother. The girl does not like it when she is interrupted, she gets fussy and angry. The mother believes it is better to simply wait until the cartoon ends. And since the cartoons are not long (several minutes) she does not find it a problem. She claims: "I understand her because I as an adult would also get mad if someone interrupted my doing something." On the other hand, the 3-year-old boy uses a smartphone for ca. 30 minutes every day. There are however, instances when the child watches cartoons for over an hour, as his father tends to fall asleep and does not control the time. The boy watches cartoons on the smartphone in the mornings and evenings, most often as a reward for eating a meal.

The interview indicates that parents of the two-year-old do not put much emphasis on creating proper conditions for the child to use the smartphone. The parents do not pay attention to the lighting, special furniture, as the child does not spend much time for using the media. Only when watching TV or using a laptop, she sits in her special chair, sometimes she watches cartoons on the laptop while sitting in her mother's office chair. Also the 3-year-old boy uses the smartphone in various circumstances, most often at the table and when going to sleep in the night.

The respondent is aware of the hazards resulting from the use of digital media, therefore her daughter uses mobile devices in a limited scope. She claims: "I’m usually afraid if it's not five minutes too long. And that's because I'm acutely aware that this is the moment when she gets used to various things, [my daughter] is so flexible that she quickly absorbs something new," something that quickly becomes a habit. However, the mother does not claim it is an addiction, she believes that the more a child has contact with mobile media, the larger the need to use them gets. During the interview, she emphasised that "a phone may be a way to »make it easier « and a shortcut.” She recalled an event where her friend tossed a tablet into his two-year-old's crib so that he could sleep longer. The father in question did not pay attention to the consequences, as he got to sleep in. After some time, he realised, through observation, that his child was not able to function without a tablet, which was a sign of addiction. The mother also indicates other hazards brought about by contemporary phone applications, which "help parents in upbringing their child." These are applications reminding the parents about feeding time, bath time or bedtime. The mother believes that these applications take away the parents' decision-making ability and give it to the phone, and that should be natural and intuitive for the parent.

In the opinion of the mother of the boy, a smartphone teaches the ability to concentrate on the contents of a media message. For the respondent, the main hazard is the excessive time of using the medium, which could lead to addiction. 
However, the mother admits that she is glad when the child is sitting peacefully and using a smartphone. She believes that at this age, the child may watch 15 minutes of a cartoon or an educational programme each day.

During the interview, the mother confirmed that she uses smartphone to post her daughter's pictures online in social media and does not see anything wrong with that. "I'm cautious to post them on my social media accounts and not my daughter's. My child is a part of my life, so from time to time, her picture will be posted. It would be wrong if I posted only her pictures. If I post pictures of my daughter, they usually have a context around them. I know that I am in charge of her online image, but I don't believe I'm entitled to it. So, I take care that, if, when she's older, she finds them on the Internet, she wouldn't be embarrassed by something I published about her. I'd like her to say 'Oh, I got cool pictures of me when I was little'.” The mother of the boy is of a different opinion, and has not published any pictures of her son online for some time. She claims that she is increasingly more aware of the fact that her son might not want those pictures circulating on the Internet when he is older. In her opinion, they could be used in an inappropriate manner in the future. The mother admitted that it was not easy because she feels a great need to "show off" her child.

The presented approach of the mother of the two-year-old girl may result from the fact that she is professionally connected with social media. She believes that generally, she has a high level of knowledge on the upbringing aspects of using the media. The woman claims that the rapidly changing technologies are a natural part of life of this generation. This not to say that she supports the option that children should be deprived of the possibility to use the media, "[...] because it would be like to take away the world they live in.” It is possible that when the child grows up to adulthood, there will be completely new technologies, and the current ones will be obsolete. A young mother does not want to use digital media as a substitute, even though after a hard day's work, it would be the simplest way to occupy the child's attention. However, she claims that what is easy and routine brings about poor results.

The mother of the three-year-old boy is aware that the manner of use of a smartphone by her husband and herself may determine attitudes of the boy in this respect in the future. The respondent uses her smartphone an average of 2 to 3 hours daily. Although she admits that when she goes to the playground with her son, she does use her smartphone from time to time, she does not consider this as a good example to follow. The respondent often observes mothers, who, instead of taking care of their children, spending time with them and focusing on their needs, use their smartphone all the time. 


\section{CONCLUSION}

The presented conclusions, though they should not be generalised, may be applied to upbringing in families similar to the ones described. In the present work, I formulated problems concerning the reasons for which mothers use smartphones in upbringing their children and the problems concerning their opinions about the possibilities and hazards connected with the use of this medium. Therefore, in result of conducted individual interviews, I have determined that the two mothers use smartphones in upbringing their children mainly in order to divert the child's attention and in result keep it sitting quietly in one place for a longer period of time. Such use of the smartphone, allowed the respondents to perform other activities. The interviews indicate that the educational functions of this medium are less important, even though the examined mothers are aware of them and attempt to utilise them in the upbringing process. The two mothers often make use of the smartphone and the Internet and are conscious of the hazards associated with excessive use of these media by children, therefore, having concerns in this respect, attempt to limit their use. At this point, I would like to note the differences in parental approaches of the participants connected with the use of the smartphone. I have determined that the mother of the two-year-old girl uses her smartphone (to watch cartoons, pictures, videos) to calm her child down in situations when she becomes troublesome, aggravated, naughty, and on the other hand the mother of the three-year-old boy does not permit such situations, so that they do not become a habit. From the perspective of child upbringing and the principles thereof, the actions of the mother of the boy are considered proper, as the smartphone should not become a "digital pacifier" which will accompany the child throughout their lives. The reason is that a risk exists that the habit developed in result of such actions shall accompany the child in school, at university and in professional work. In the future, the nervous adult will habitually make use of the mobile device in order to calm down, ignoring their surroundings. Another difference applies to the use of the smartphone during family meals. The mother of the two-year-old girl does not allow such situations to occur and the mother of the three-year-old boy admits that during meals, the father often uses his smartphone and it happens that the boy watches cartoons on a smartphone while eating. The last difference concerns the use of the camera function of the smartphone. Although both mothers use their smartphones to take pictures, only the mother of the girl posts the pictures of her child on social media. Posting pictures of children by parents online has become increasingly popular procedure, which in literature is called "sharenting” (Brosch, 2017). 
In conclusion, the attitudes of both mothers towards using smartphone in upbringing their children are quite similar. Differences concern, in particular, treating smartphone as a digital pacifier, because only one mother uses smartphone to calm down a baby.

This research has shown that problem of using smartphones by toddlers is most pressing and yet not discovered enough. Therefore, there is a need to continue quantities and qualities research which will allow to discover a lot of aspects of this phenomenon.

\section{References:}

Applet, K. (2005). Wiek poniemowlęcy. Jak rozpoznać potencjał dziecka? In: A.I. Brzezińska (Ed.), Psychologiczne portrety człowieka (pp. 95-130). Gdańsk: Gdańskie Wydawnictwo Psychologiczne.

Applet, K., \& Mielcarek, M. (2014). Opieka i wychowanie. Wczesne dzieciństwo. Niezbędnik Dobrego Nauczyciela. Series 2, Vol. 1. Warszawa: Wydawnictwo Instytut Badań Edukacyjnych.

Bassiouni, D.H., \& Hackley, Ch., (2013). Does Early Exposure to Digital Media Harm Children's Development? A Cross-Disciplinary Review. Working Paper Series. SoMWP-1302. School of Management, Royal Holloway University of London.

Batorski, D. (2017). Dzieci z sieci - dostęp i korzystanie z internetu przez dzieci w wieku przedszkolnym. In: J. Pyżalski (Ed.), Małe dzieci w świecie technologii informacyjnokomunikacyjnych. Pomiędzy utopijnymi szansami a przesadzonymi zagrożeniami (pp. 7994). Łódź: Wydawnictwo Eter.

Berk, R.A. (2009). Teaching Strategies for the Net Generation, Transformative Dialogues: Teaching and Learning Journal, 3(2), pp. 1-24.

Björklund, A., \& Salvanes, K.G. (2010). Education and Family Background: Mechanism and Policies. In: E.A. Hanushek, S.J. Machin, \& L. Woessmann (Eds.), Handbook of the Economics of Education (pp. 201-243). Burlington: Elsevier Science.

Brosch, A. (2016). When the Child Is Born into the Internet. Sharenting as a Growing Trend among Parents on Facebook, The New Educational Review, 43(1), pp. 225-235.

Genc, Z. (2014). Parents' Perceptions about the Mobile Technology Use of Preschool Aged Children, Procedia: Social and Behavioral Sciences, 146, pp. 55-60. DOI:10.1016/ j.sbspro.2014.08.086

Hosch, W.L. Smartphone. In: Encyclopaedia Britannica. Retrieved from: https://www.britannica.com/technology/smartphone (doa 09.03.2017).

Huk, T. (2013). Media jako czynnik wspierający rozwój dziecka w wieku przedszkolnym. In: J. Morbitzer, \& E. Musiał (Eds.), Człowiek-Media-Edukacja (pp. 137-145). Kraków: Wydawnictwo Katedra Technologii i Mediów Edukacyjnych Uniwersytet Pedagogiczny.

Juszczyk, S. (2013). Badania jakościowe w naukach społecznych. Szkice metodologiczne. Katowice: Wydawnictwo Uniwersytetu Śląskiego.

Kim, J.K., \& Kang, Y.S. (2016). The Effects of Young Children's Smartphone Use Experience on Their Parents' Perceptions and Needs and Their Self-Regulation, International Journal of Applied Engineering Research, 11(2), pp. 1208-1211. 
Kuszak, K. (2017). Charakterystyka rozwoju dziecka w wieku 3-6 lat. In: J. Pyżalski (Ed.), Małe dzieci w świecie technologii informacyjno-komunikacyjnych. Pomiędzy utopijnymi szansami a przesadzonymi zagrożeniami (pp. 11-60). Łódź: Wydawnictwo Eter.

Lauricella, A.R., Wartella, E., \& Rideout, V.J. (2015). Young Children’s Screen Time: The Complex Role of Parent and Child Factors, Journal of Applied Developmental Psychology, 36, pp. 11-17. DOI: 10.1016/j.appdev.2014.12.001

Madge, C., \& O’Connor, H. (2006). Parenting Gone Wired: Empowerment of New Mothers on the Internet, Social and Cultural Geography, 7(2), pp. 199-220.

Plowman, L., McPake, J., \& Stephen, C. (2011). The Technologisation of Childhood? Young Children and Technology in the Home, Children \& Society, 24(1), pp. 63-74. DOI: 10.1111 /j.1099-0860.2008.00180.xpp

Plichta, P. (2017). Małe dzieci z zaburzeniami rozwojowymi i ich rodzice jako adresaci działań wykorzystujących technologie informacyjno-komunikacyjne. In: J. Pyżalski (Ed.), Małe dzieci w świecie technologii informacyjno-komunikacyjnych. Pomiędzy utopijnymi szansami a przesadzonymi zagrożeniami (pp. 95-114). Łódź: Wydawnictwo Eter.

Prensky, M. (2001). Digital Natives, Digital Immigrants, Part 1. On the Horizon, 9(5), pp. 1-6. West Yorkshire: MCB University Press.

Pyżalski, J. (2017). Dzieci w wieku przedszkolnym w świecie technologii informacyjnokomunikacyjnych - w stronę zagrożeń. In: J. Pyżalski (Ed.), Małe dzieci w świecie technologii informacyjno-komunikacyjnych. Pomiędzy utopijnymi szansami a przesadzonymi zagrożeniami (pp. 159-182). Łódź: Wydawnictwo Eter.

Rubacha, K. (2008). Metodologia badań nad edukacją. Warszawa: Wydawnictwa Akademickie i Profesjonalne.

Siemieniecki, B. (2013). Pedagogika kognitywistyczna. Studium teoretyczne. Kraków: Oficyna Wydawnicza Impuls.

Śliwerski, B. (2012). Pedagogika ogólna. Podstawowe prawidłowości. Kraków: Oficyna Wydawnicza Impuls.

Wartella, E., Rideout, V., Lauricella, A., Connell, S. (2014). Parenting in the Age of Digital Technology: A National Survey. Report of the Center on Media and Human Development, School of Communication. Northwestern University, October 3rd. Retrieved from: cmhd. northwestern.edu

Yoon, K.W. (2003). Retraditionalizing the Mobile: Young People’s Sociality and Mobile Phone Use in Seoul, South Korea, European Journal of Cultural Studies, 6(3), pp. 327-343. 